\title{
Discussant's Remarks: Reviving Ethnology to Understand the Rice Neolithic
}

\author{
Richard A. O'Connor
}

Received: 21 October 2011 /Accepted: 2 November 2011 /Published online: 15 December 2011

(C) Springer Science+Business Media, LLC 2011

Our symposium's rationale, "rapid advances" in genetics, linguistics, and archaeology, makes no mention of my field, cultural anthropology. Nor should it. It's regress, not progress - at least on these matters. As Fiskesjö said on the first day, the discipline dismisses origins. Immersed in the moment, today's cultural anthropology studies each group in itself and by itself. That's ethnography. What the rice/language puzzle needs is ethnology, a comparative approach. Yet there is no full-scale, culture-crossing, in-depth analysis of how rice-growing groups do and don't differ. Cultural anthropology has tools for that task but no inclination. We'll tell you how rice is 'culturally constructed,' not how cultures might be rice-constructed.

An ethnology of rice might begin by studying crop/culture interdependence. Once scholars debated whether the distinctive labor conditions of wet rice explained the better condition of women in Southeast Asia (Goldschmidt and Kunkel 1971; Moore 1973; Winzeler 1974) but that thought disappeared once gender became culturally constructed. Then there's how the small-scale intricacy of wet rice turns Wittfogel's (1957) oriental despotism on its head. Here local autonomies that Bray (1986: 27, 173-79) documents for South China under the Han appear in the coastal American South under slavery. Allowed to manage what overseers couldn't control, rice-growing slaves fared better than their cotton- and sugar-growing counterparts. While rice-growers developed local subsistence activities, kept more of their African heritage and held on to a Creole, those suffering cotton and sugar regimens had no such buffers.

R. A. O'Connor $(\bowtie)$

Department of Anthropology, Sewanee: University of the South, Sewanee, TN 37383, USA

e-mail: roconnor@sewanee.edu
Different crops, it seems, created different worlds (see Mintz (2010: 30-31) on sugar).

Rice-made worlds have the power to displace other crops and remake their cultures. Slowly but surely the rizification of Asia has created cultures where "rice" means "food," defines key rituals, or both. Somehow rice reorganizes everyday life around itself. By historic times, when outsiders describe the change, some Southeast Asians turn to rice as if it were an addiction, not a subsistence (O'Connor 1995, 986 fn6). Is it the taste? The higher status? However it begins, rice growing can develop from a livelihood into a lifestyle. Does commensality do this culture shaping? Is it the moral density of interdependence, of working together as a community? Arguably that's how wet rice involutes (Geertz 1963). The group turns inward, intensifying and thereby specializing rather than hiving off. That's classic Durkheim (1964), exactly what he theorized as organic solidarity. His other society making bond, the mechanical solidarity of simple similarity, creates fractious groups. That then suggests why dry rice peoples expand precipitously, spinning off households long before population density demands it. Competitive factionalism might well have energized the Austronesian dispersal.

Were we to plot mainland Southeast Asia's long-term agricultural development, it suggests wet rice and dry were caught up in-or inspired?-grassroots movements that polarized the region around their differences. On the one hand, over perhaps a thousand years, villageorganized Burmese, Tai and Vietnamese displace householdorganized Austroasiatics (O’Connor 1995). Agriculturally, intensive wet rice replaces an extensive rice/house gardening mix; linguistically, Tai replaces Mon in what is now Thailand's Central Plains; and, politically, flexible alliance building states replace their rigid temple-centered predecessors (Kirsch 1984; O'Connor 2000). On the other 
hand, dry rice organizes the uplands around household farming and state-avoidance, creating what Scott (2009) calls Zomia.

Are these two independent movements, each pulling the region apart? Or is this symbolic differentiation, drawing the region together? I favor the latter: even as groups diverge agriculturally and geographically they converge symbolically in a discourse that stereotypes differences. So instead of isolated groups, each going its own way, we see ready movement across cultural boundaries as well as ritual integration across the so-called upland/lowland divide, all evidence of close communication. Arguably, rice energizes this regionmaking, acting as both a common denominator and a culture-crossing idiom of hospitality (e.g., Matisoff 1983). Certainly the expectation that one shares rice and rice wine freely creates camaraderie exactly where dividing meat imposes a restrictive hierarchy.

At first glance, insular Southeast Asia's agricultural development is simpler. As Bellwood (this volume) tells it, Austronesian farmers displace earlier hunters and gatherers. Yet some archaeologists say this slights local diversity (Szabo and O'Connor 2004) and, if we factor in a prior Austroasiatic presence in Borneo (Blench 2010), perhaps the expanding Austronesians met a vegetal culture like what Sidwell (2011) and White (2011) propose for the mainland. In theorizing this encounter, the complementary dualism that pervades insular Southeast Asia (Fox 1987) takes on new meaning. Is it a legacy of that encounter or a cultural tool that sped Austronesian expansion? Either way it suggests how newcomers and autochthons might have grown together, creating a single society by a symbolic division of labor.

What I've said thus far interprets the past with current concepts, yet I suspect that adequately addressing the Neolithic rice/language nexus will require three conceptual shifts. First, a foundation of modern thought, Cartesian Dualism, rips "crop" and "culture" asunder whereas farming weaves them together. We're primed to imagine individual farmers choosing crops pragmatically whereas growing rice is often better understood as a total social phenomenon (Mauss 1967), a community activity that is not just practical but moral, aesthetic, political, religious, and ethnic too.

Second, our current concepts of "culture" and "language" presume a separateness of groups that Southeast Asia insistently defies. What linguists call areal features (Enfield 2005) are but part of a larger metacultural discourse whereby groups communicate across linguistic and cultural divides. No doubt it helps that Southeast Asia's diverse peoples are mostly "cousins," offspring of the South China Neolithic. So they're historically primed to understand neighbors as variations on their own themes. Yet the region also has well-established traditions that breed areal interconnectedness out of everyday life-multilingualism, male wandering, hospitality gestures, travel customs, deference to local rule-making (Adat in the Islands), openness to social entrepreneurs (Hanks 1971). Here, Southeast Asia, as the further edge of the South China Neolithic, may preserve patterns long lost in the core area.

Third, current concepts of "culture" and "language" also slight how rice growing is an "activity complex." As a taskcentered body of practice, an activity follows its own inner logic and develops its own customs quite apart from what culture or language decrees. Of course this separatenesswhat we might call the relative autonomy of a key activitydoesn't apply just to rice. Take our symposium. Did it matter that we gathered in Ithaca and emphasized English? A bit perhaps but not a lot. We understood each other-once as scholars (sharing scholarship as a practice), again as specialists (sharing rice as a subject), and perhaps yet again as interlocutors of rice (joined in how the plant answers our probes). And while our mutual understanding unites us across cultural and linguistic divides, it divides us from others who share our culture and language but not our rice-given understandings. Are rice growers all that different from rice scholars? Imagine a chain of marriages between wet rice villages: a Malay marries into a Tai village, Tai into Mon, Mon into Burmese - crossing four language families. Yes, the newcomers would learn new words but how new would growing rice be? Don't misunderstand-I'm not a rabid reductionist. Just the contrary: I'm saying a practice (growing rice in this instance) has an integrity that can never be reduced to how a specific culture (Tai for example) defines it.

An ethnology of rice argues for these three conceptual shifts. Taken together, they give us a more nuanced view of how rice, language, and culture interconnect for historic Southeast Asia. That gives us firmer ground for understanding prehistory and distinguishing human universals from historical particulars. How much of what archaeology and historical linguistics have come to take as natural is only Indo-European? We won't know until the world's other major traditions are better studied, but what we've just described as distinctive for Southeast Asia would impact both the pacing and cultural packaging of linguistic and agricultural change.

\section{References}

Blench R (2010) Was There an Austroasiatic presence in Island SE Asia prior to the Austronesian expansion? Draft. www.rogerblench. info. Accessed 19 Oct 2011.

Bray F. The rice economies: technology and development in Asian societies. New York: Basil Blackwell; 1986.

Durkheim E. The division of labor in society. New York: Free Press; 1964. 
Enfield NJ. Areal linguistics and Mainland Southeast Asia. Annu Rev Anthropol. 2005;34:181-206.

Fox JJ (1987) Southeast Asian religions: insular cultures. Mircea Eliade (ed). The encyclopedia of religion.vol. 13. New York: Macmillan.

Geertz C. Agricultural involution: the processes of ecological change in Indonesia. Berkeley: University of California Press; 1963.

Goldschmidt W, Kunkel EJ. The structure of the peasant family. Am Anthropol. 1971;73:1058-76.

Hanks LM (1971) Corruption and commerce in Southeast Asia. Transaction 8(7):18-25, 53.

Kirsch AT. Cosmology and ecology as factors in interpreting early Thai social organization. Journal of Southeast Asian Studies. 1984;15 (2):253-65.

Matisoff JA. Linguistic diversity and language contact. In: McKinnon J, Bhruksasri W, editors. Highlanders of Thailand. Kuala Lumpur: Oxford University Press; 1983. p. 56-86.

Mauss M. The gift: forms and functions of exchange in Archaic societies. New York: Norton; 1967.

Mintz SW. Three ancient colonies: Caribbean themes and variations. Cambridge: Harvard University Press; 2010.

Moore M. Cross-cultural surveys of peasant family structures: some comments. Am Anthropol. 1973;75:911-5.
O'Connor RA. Agricultural change and ethnic succession in Southeast Asian states: a case for regional anthropology. Journal of Asian Studies. 1995;54(4):968-96.

O'Connor RA. (2000) A regional explanation of the Tai Muang as a city-state. In: A comparative study of thirty city-state cultures, edited by Mogens Herman Hansen. Copenhagen, Denmark: The Royal Danish Academy of Sciences and Letters

Scott JC. The art of not being governed: an anarchist history of upland Southeast Asia. New Haven: Yale University Press; 2009.

Sidwell P. Correlating the lexicon and dispersal of Proto-Austroasiatic with the arrival of rice agriculture in Mainland SE Asia. Poster at "Rice and Language Across Asia: Crops, Movement and Social Change." International Symposium. Ithaca: Cornell University; 2011. September 22-25.

Szabo K, O'Connor S. Migration and complexity in holocene Island Southeast Asia. World Archaeology. 2004;36(4):621-8.

White JC. Emergence of cultural diversity in Mainland Southeast Asia: a view from prehistory. In: Enfield NJ, editor. Dynamics of human diversity. Canberra: Pacific Linguistics; 2011.

Winzeler RL. Sex role equality, wet rice cultivation and the state in Southeast Asia. Am Anthropol. 1974;76:563-7.

Wittfogel KA. Oriental despotism: a comparative study of total power. New Haven: Yale University Press; 1957. 